\title{
Shear Modulus and Shear Strength Evaluation of Solid Wood by a Modified ISO 15310 Square-Plate Twist Method
}

\section{Procjena smicajnog modula i smicajne čvrstoće cjelovitog drva modificiranom metodom prema normi ISO 15310}

\author{
Preliminary paper • Prethodno priopćenje \\ Received-prispjelo: 22. 7. 2011. \\ Accepted-prihvaćeno: 9. 2. 2012. \\ UDK: $630 * 812.74$ \\ doi:10.5552/drind.2012.1125
}

\begin{abstract}
Square-plate twist (SPT) tests were conducted to measure the shear modulus and shear strength using the method, which was a modification of the International Organization for Standardization (ISO 15310) standardized method. In the SPT test, the length/thickness ratio varied. In addition, asymmetric four-point bending (AFPB) tests were conducted, and the shear modulus and shear strength obtained were compared with those obtained by the SPT tests. The shear modulus was obtained effectively by the SPT test when the specimen was thin enough. Although the shear strength was evaluated as higher than that obtained by the AFPB tests, it might be regarded as an apparent value of shear strength when the range of length/thickness is limited. To obtain the actual shear strength by the SPT test, some modification of the equation is required.
\end{abstract}

Keywords: shear strength, square-plate twist (SPT) test, asymmetric four-point bending (AFPB) test

SAŽETAK • Testovi uvijanja kvadratne ploče (SPT) provedeni su radi mjerenja smicajnog modula i smicajne čvrstoće primjenom metode koja je modificirana standardna metoda definirana međunarodnim standardom ISO 15310. U SPT testu variran je omjer duljine i debljine uzorka. Osim toga, proveden je i test asimetričnog savijanja u četiri točke (AFPB) a dobiveni smicajni moduli i smicajna čvrstoća uspoređeni su s onima dobivenim SPT testom. Stvarna vrijednost smicajnog modula dobije se SPT testom ako su uzorci dovoljno tanki. Premda su vrijednosti smicajne čvrstoće veće od onih dobivenih AFPB testom, moguće ih je promatrati kao vrijednosti smicajne čvrstoće kada je omjer duljine i debljine uzoraka ograničen. Da bi se SPT testom dobile stvarne vrijednosti smicajne čvrstoće, nužna je modifikacija jednadžbi za određivanje smicajne čvrstoće.

Ključne riječi: smicajna čvrstoća, test uvijanja kvadratne ploče (SPT), test asimetričnog savijanja u četiri točke (AFPB test)

\footnotetext{
Author is professor at the Faculty of Science and Engineering, Shimane University, Matsue, Shimane, Japan.

Autor je profesor Fakulteta znanosti i tehnike Sveučilišta Shimane, Matsue, Shimane, Japan.
} 


\section{INTRODUCTION}

\section{UVOD}

Various testing methods have been proposed for determining the shear properties of solid wood (Yoshihara, 2006). Among them, torsion testing is attractive because a rather pure shear stress condition can be induced in the material (Timoshenko and Goodier, 1987). Square-plate twist (SPT) testing is an application of torsion testing, and it has been standardized as a way of measuring the edgewise shear modulus of plywood and fiber-reinforced plastics in ASTM D3044-94 (ASTM, 2005) and ISO 15310-99 (ISO, 1999), respectively. These standards determine the measurement of shear modulus alone. If the SPT enables the proper measurement of shear strength as well as that of shear modulus, however, it will be applied frequently because it is an application of torsion testing and can be conducted easily. In the present research, we examined the validity of a modified ISO 15310 method for the measurement of shear strength using Sitka spruce.

\section{MATERIALS AND METHODS}

\section{MATERIJALI I METODE}

Sitka spruce (Picea sitchensis Carr.) lumber was used for the tests. The density was $400 \mathrm{~kg} / \mathrm{m}^{3}$ at $12 \%$ moisture content. The specimens cut from the lumber were side matched. During cutting the specimens, the defects such as knots, grain distortion, and grain orientation were removed, so the specimen could be regarded as "small and clear." Seven specimens were used for each test condition.

Figure 1 shows a diagram of the SPT test according to the modified ISO 15310 method. Specimen $B$ was 140 long and $140 \mathrm{~mm}$ wide; its thickness, $H$, varied from 3 to $15 \mathrm{~mm}$ at intervals of $3 \mathrm{~mm}$. The $x, y$, and $z$ directions coincided with the longitudinal (L), tangential $(\mathrm{T})$, and radial $(\mathrm{R})$ directions, respectively, so the shear stress and shear strain in the LT plane are designated $\tau_{\mathrm{LT}}$ and $\gamma_{\mathrm{LT}}$, respectively. In the ASTM D 3044 method, a metal plate must be attached to each corner of the specimen for applying the loads just at the corners. The corner plates may restrict the saddle-like deformation in the specimen, and a combined stress condition induced at the corners may distribute widely in the specimen. In contrast, these plates are not required in the ISO 15310 method, so the saddle-like deformation is not restricted. The ISO 15310 method was, therefore, adopted in this experiment. Figure 2(a) shows the photograph of the ISO 15310 SPT test actually conducted in this investigation.

The specimen was supported and loaded at the moment arm, $W$, of $130 \mathrm{~mm}$ (Fig. 1). The radius of the support and loading points was $15 \mathrm{~mm}$. Load $P$ was applied at a crosshead speed of $5 \mathrm{~mm} / \mathrm{min}$ until the specimen separated into two pieces. The loading-line deflection, $\delta$, was obtained from the crosshead movement. The total testing time was about 5-10 $\mathrm{min}$. The shear stress at the center of the LT plane, $\tau_{\mathrm{LT}}$, in the SPT test was obtained from the following equation (Timoshenko and Goodier, 1987):

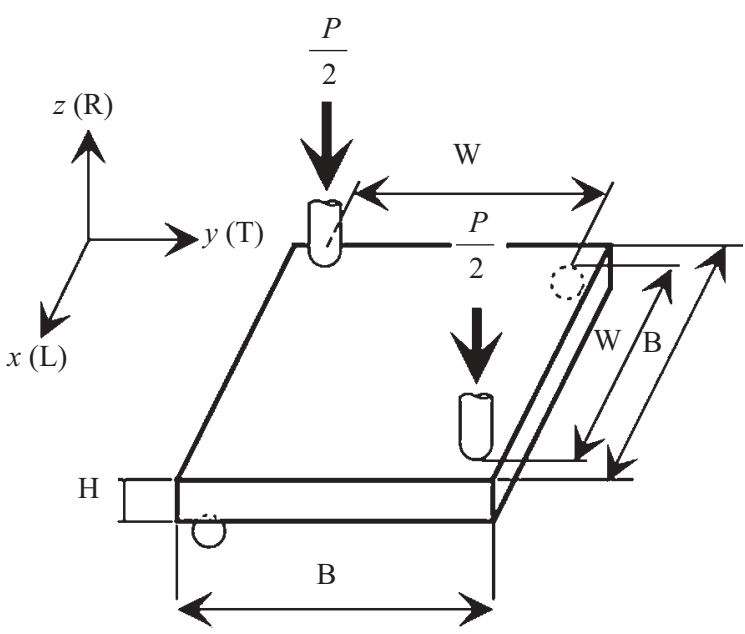

Figure 1 ISO 15310 square-plate twist method; L, T, and R, represent the longitudinal, tangential, and radial directions, respectively

Slika 1. Metoda uvijanja kvadratne ploče prema normi ISO 15310; L, T i R označavaju uzdužni, tangencijalni i radijalni smjer

$$
\tau_{\mathrm{LT}}=\frac{3 \cdot P \cdot W}{2 \cdot B \cdot H^{2}}
$$

Using $\delta, \gamma_{\mathrm{LT}}$ was also obtained as follows (ISO $153101999)$ :

$$
\gamma_{\mathrm{LT}}=\frac{2 \cdot W \cdot H}{K \cdot B^{3}} \cdot \delta
$$

where $K$ is the correction factor for the shifted position of the loading points, which is derived as follows (ISO 15310 1999):

$$
K=3\left(\frac{W}{B}\right)^{2}-2\left(\frac{W}{B}\right)-2\left(1-\frac{W}{B}\right)^{2} \ln \left(1-\frac{W}{B}\right)
$$

The shear modulus in the LT plane $G_{\mathrm{LT}}$ was determined from the initial slope of the $\tau_{\mathrm{LT}} \gamma_{\mathrm{LT}}$ relationship. The shear strength in the LT plane, $S_{\mathrm{LT}}$, was determined by substituting the maximum load into Eq. (1).

The asymmetric four-point bending (AFPB) test, the validity of which was verified in a previous study (Yoshihara, 2009), was conducted using a notched specimen, and $G_{\mathrm{LT}}$ and $S_{\mathrm{LT}}$ obtained were compared with those obtained from the SPT method. Figure 2(b) shows the photograph of the AFPB test. A beam specimen with the dimensions of $340(\mathrm{~L}) \times 30(\mathrm{~T}) \times 12(\mathrm{R})$ $\mathrm{mm}^{3}$ was initially prepared. Straight-through notches were cut at mid-span of the top and bottom surfaces of the specimen, which corresponded to the LR planes, by a circular saw (thickness $=3 \mathrm{~mm}$ ). The depth of the notch was $10 \mathrm{~mm}$, so the distance between the notch roots was $10 \mathrm{~mm}$. A biaxial strain gauge, which was similar to that used in the SPT test, was bonded at both centers of the side surfaces (LT plane) to measure the shear strain $\gamma_{\mathrm{LT}}$. The total span length was $300 \mathrm{~mm}$, and the specimen was supported eccentrically at two trisected points. Load $P$ was applied to the remaining two trisected points at the crosshead speed of $2 \mathrm{~mm} / \mathrm{min}$ until the load markedly decreased. The total testing time was about 5 min. $\tau_{\text {LT }}$ in the AFPB test was obtained using the following equation: 

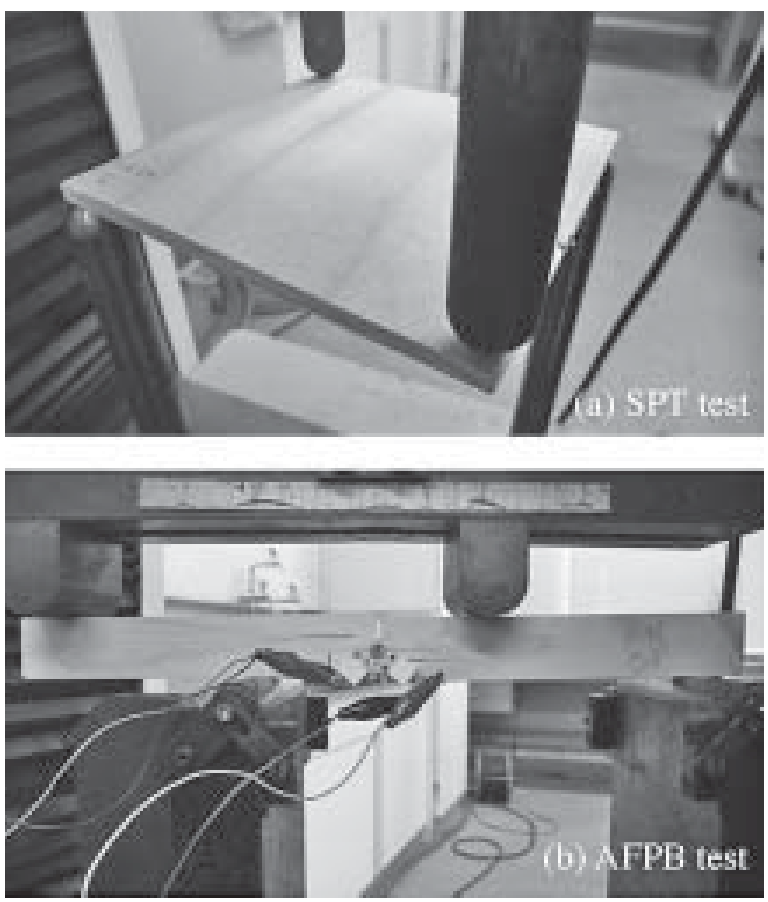

Figure 2 Photographs of the (a) ISO 15310 square-plate twist (SPT) test and (b) asymmetric-four point bending (AFPB) test

Slika 2. a) Fotografija testa uvijanja kvadratne ploče (SPT testa) prema normi ISO 15310; b) fotografija testa asimetričnog savijanja u četiri točke (AFPB testa)

$$
\tau_{\mathrm{LT}}=\frac{P}{2 \cdot b \cdot h}
$$

where $b$ is the width of the specimen and $h$ is the distance between the notches. $\gamma_{\mathrm{LT}}$ was obtained from the strain gauge output. Similar to the SPT twist method, $G_{\text {LT }}$ was measured from the initial slope in the $\tau_{\mathrm{LT}}-\gamma_{\mathrm{LT}}$ relationship, whereas $S_{\mathrm{LT}}$ was derived from the maximum stress.

\section{RESULTS AND DISCUSSION \\ 3. REZULTATI I RASPRAVA}

Figure 3 shows typical $\tau_{\mathrm{LT}}-\gamma_{\mathrm{LT}}$ relationships obtained by the SPT and AFPB tests. In the SPT test, $\tau_{\mathrm{LT}}$ continuously increases with the increase of $\gamma_{L T}$. This tendency is different from that obtained from the AFPB test, which is convex. It is attributed to the geometrical nonlinearity in loading. Equation (1) is derived on the basis that the load is applied vertically to the specimen. When the specimen has a small thickness, however, the deflection increases so markedly that the load is applied obliquely to the surface of the specimen. The shear stress obtained using Eq. (1) is therefore larger than that actually induced and the concavity in $\tau_{\mathrm{LT}}-\gamma_{\mathrm{LT}}$ relationship is induced.

Figure 4 shows a comparison of $G_{\mathrm{LT}}$ obtained from the SPT and AFPB tests. Statistical analysis of the difference between the $G_{\mathrm{LT}}$ values obtained using the SPT and AFPB tests revealed that the $G_{\mathrm{LT}}$ value was significantly smaller than the results obtained by the AFPB test, except for that with $H=3 \mathrm{~mm}$, at the significance level of 0.01 . In addition, the $G_{\mathrm{LT}}$ value obtai-

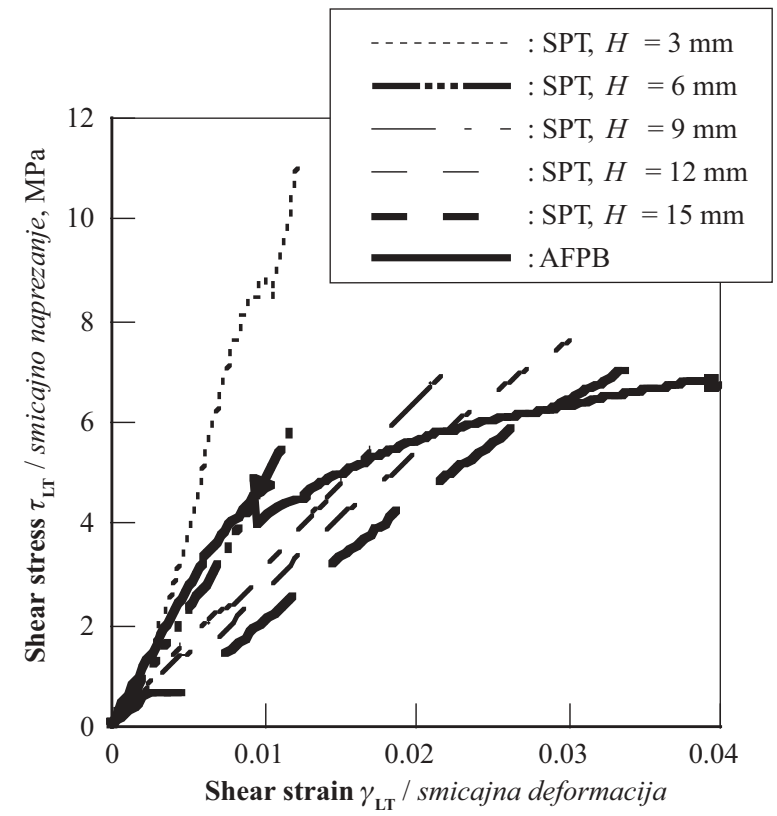

Figure 3 Comparison of the shear stress/shear strain relationships obtained by the different methods (SPT square-plate twist method; AFPB - asymmetric four-point bending method)

Slika 3. Usporedba odnosa smicajnog naprezanja i deformacija dobivenih različitim metodama (SPT - metoda uvijanja kvadratne ploče; AFPB - metoda asimetričnog savijanja u četiri točke)

ned using the SPT test decreases with the increase of thickness of specimen. The statistical analysis also revealed they are different from each other at the significance level of 0.01 . These tendencies, which were similar to the results obtained in a previous work (Yoshihara and Sawamura, 2006), are the consequence of the three-dimensional effect. When the global deflection is measured, the shear stress in the radial-tangential plane $\tau_{\mathrm{RT}}$ is significant and it reduces the measured value of $G_{\mathrm{LT}}$ as the plate gets thicker.

Figure 5(a) shows a comparison of $S_{\mathrm{LT}}$ values obtained from the SPT and AFPB tests. The statistical analysis for the $S_{\mathrm{LT}}$ values obtained from the SPT and AFPB tests reveals that the values of $S_{\mathrm{LT}}$ obtained from the SPT test are significantly larger than those obtained from the AFPB test at the significance level of 0.01 except for that of $H=6 \mathrm{~mm}$. The large value of $S_{\mathrm{LT}}$ obtained by the SPT is because of the large deflection during the test. Due to large deflection, the load is applied obliquely to the specimen surface. The torsional moment induced by oblique loading is smaller than that induced by vertical loading, so the shear stress actually induced may be smaller than that derived by Eq. (1). As shown in Figure 5(b), which shows the maximum deflection $\delta_{\text {max }}$ corresponding to the specimen's thickness $H$, the value of $\delta_{\text {max }}$ of $H=3 \mathrm{~mm}$ is significantly larger than those of the specimen with the larger thickness, so the deflection may influence the measurement of $S_{\mathrm{LT}}$. According to the previous study (Yoshihara and Sawamura, 2006), the edgewise shear modulus can be measured appropriately by the modified ISO 15310 AFPB test when the specimen is thin enough. Nevertheless, the result described above suggests that 


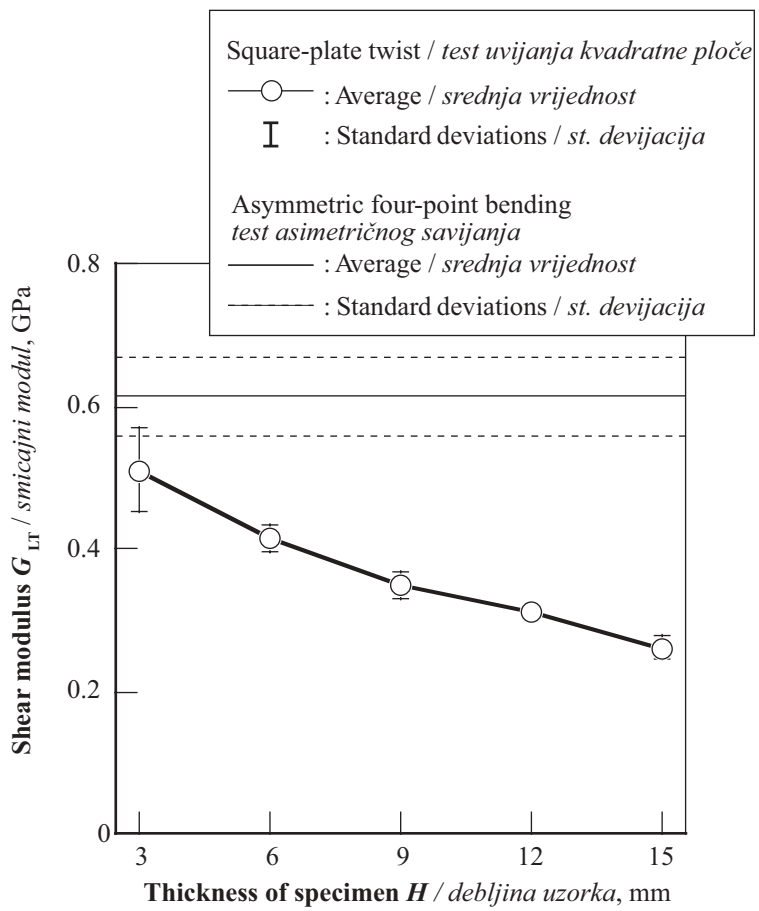

Figure 4 Shear modulus corresponding to the thickness of the specimen obtained by the square-plate twist test, and comparison with results obtained by the asymmetric fourpoint bending tests

Slika 4. Ovisnost smicajnog modula o debljini uzorka dobivena testom uvijanja kvadratne ploče i usporedba s rezultatima dobivenim testom asimetričnog savijanja u četiri točke

the specimen should not be thin for measuring the shear strength of wood by the AFPB test.

When conducting the statistical analysis for the $S_{\text {LT }}$ values obtained using the SPT tests, there are no differences among the values of $S_{\mathrm{LT}}$ of $H=6,9,12$, and $15 \mathrm{~mm}$. The statistical analysis for the $\delta_{\max }$ values also reveals that there are no differences among the values of $\delta_{\max }$ in this range of $H$. The shear strength of solid wood is often evaluated by the shear-parallel-to-grain test method standardized in the ASTM D143 (ASTM 2005) although the shear strength obtained is regarded as an apparent property and is not the actual strength of the material. The results obtained here suggest the feasibility that the $S_{\mathrm{LT}}$ value obtained from the SPT test might be regarded as an apparent value of shear strength when the range of length/thickness is limited while reducing the large deflection during the test.

In many shearing tests, including the ASTM D143 test, specimen often fails at the loading and/or supporting points of the specimen where the combined stress condition is induced. In the SPT test, however, it should be noted that the specimen failed along the fiber direction at the mid-plane of wider surface, which is far from the loading and supporting points. This issue indicates the advantage of the SPT test over the other tests, and shows why it is attractive to conduct the SPT test. Further research should be conducted to modify Eq. (1) for obtaining the shear strength of solid wood more properly while considering the large deflection.

\section{CONCLUSIONS}

\section{ZAKLJUČCI}

A modified ISO 15310 square-plate twist test of Sitka spruce was conducted to obtain the shear strength in the longitudinal-tangential plane using specimens with various thicknesses. In addition to the square-plate twist test, the asymmetric four-point bending test
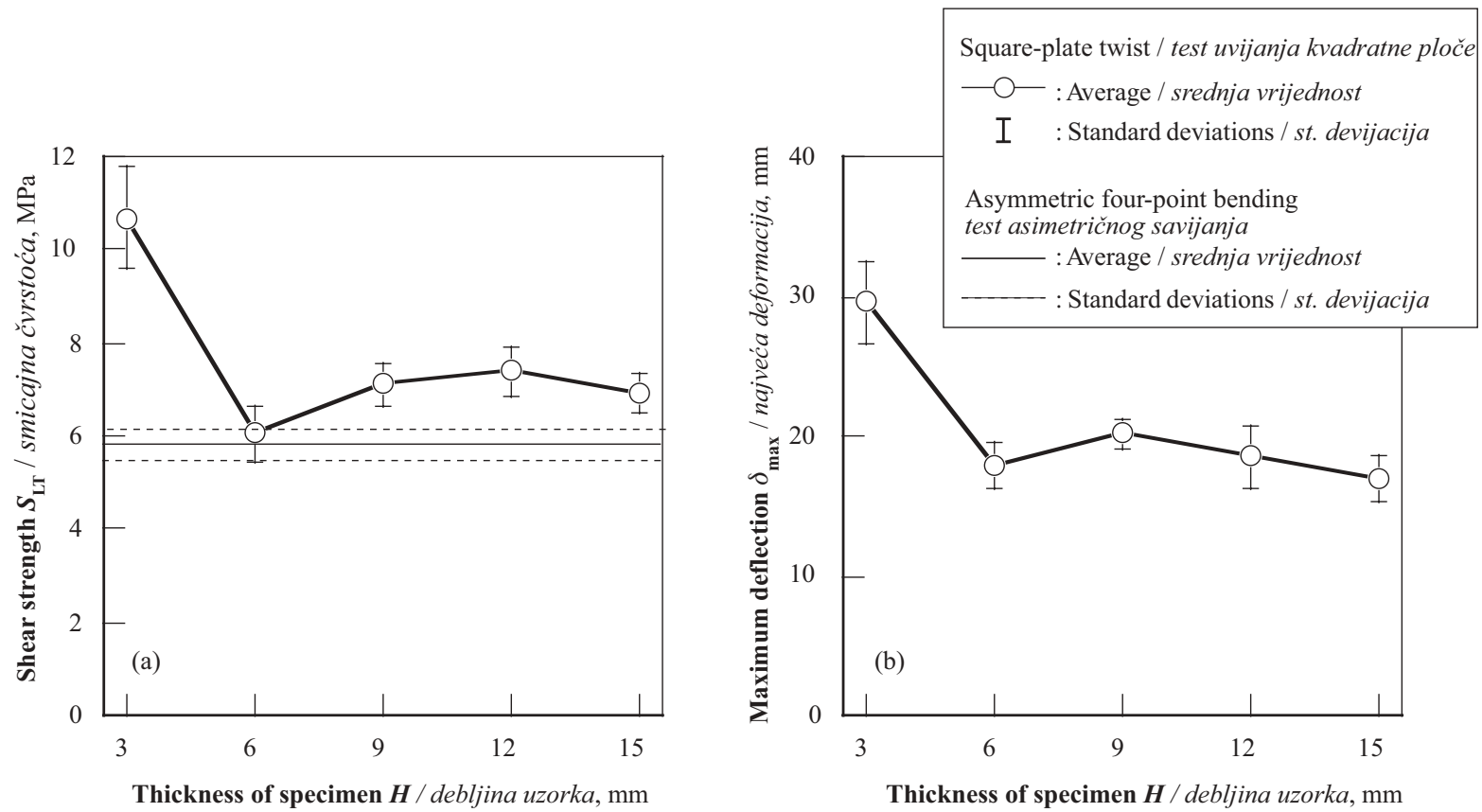

Figure 5 (a) Shear strength corresponding to the thickness of the specimen obtained by the square-plate twist test, and comparison with results obtained by the asymmetric four-point bending tests, and (b) Maximum deflection corresponding to the thickness of the specimen obtained by the square-plate twist test

Slika 5. Ovisnost smicajne čvrstoće o debljini uzorka dobivena testom uvijanja kvadratne ploče i usporedba s rezultatima dobivenim testom asimetričnog savijanja u četiri točke, b) ovisnost maksimalne deformacije o debljini uzorka dobivena testom uvijanja kvadratne ploče 
was performed, and the results were compared with those of the square-plate twist tests.

It is feasible that shear strength obtained from the square-plate twist method could be regarded as an apparent value of shear strength, which is larger than that obtained by the asymmetric four-point bending test because of the large deflection. To increase the accuracy of the measurement, further research should be undertaken to modify the equation for obtaining the shear strength while considering the large deflection.

\section{REFERENCES}

\section{LITERATURA}

1. Timoshenko, S. P.; Goodier, J. N., 1987: Theory of elasticity 3rd edition. McGraw-Hill, New York.

2. Yoshihara, H.; Sawamura, Y., 2006: Measurement of the shear modulus of wood by the square-plate twist method. Holzforschung 60(5): 543-548, http://dx.doi.org/10.1515/ HF.2006.090.

3. Yoshihara, H., 2009: Shear properties of wood measured by the asymmetric four-point bending test of notched specimen. Holzforschung 63(2): 211-216, http://dx.doi.org/10.1515/HF.2009.035.

4. ***ASTM D 143-94. 2005. Standard test methods for small clear specimens of timber. American Society for Testing and Materials, West Conshohocken, USA.

5. ***ASTM D 3044-94. 2005. Standard test methods for shear modulus of wood-based structural panels. American Society for Testing and Materials, West Conshohocken, USA.

6. ***ISO 15310-99. 1999. Fibre-reinforced plastic composites- Determination of the in-plane shear modulus by the plate twist method. International Organization for Standardization, Geneva, Switzerland.

\section{Corresponding address:}

Professor HIROSHI YOSHIHARA, Ph.D.

Shimane University

Faculty of Science and Engineering

Nishikawazu-cho 1060

Matsue, Shimane 690-8504, JAPAN

e-mail: yosihara@riko.shimane-u.ac.jp 